\title{
THE GRASS GRUB PROBLEM IN THE HILI COUNTRY OF THE CENTRAL PLATEAU
}

\author{
R. B. GORDON \\ Advisory Services Division, Department of Agriculture, Taupo \\ W. M. KaIN \\ Research Division, Department of Agriculture, Hamilton
}

\section{Summary}

In as yet isolated districts within the central plateau region, serious outbreaks of grass grub have proved economically crippling for those farmers who have been attacked. A postal survey has indicated that over $65 \%$ of the farmers in the Taupo Advisory District of the Department of Agriculture have areas of grass grub damage on their properties and $43 \%$ of these consider current damage to be severe. In the Mangakino district, grass grub has been a major contributing factor leading to the resettlement of dairy farmers and the phasing out of dairy farming within the area. A sample of five farms chosen from a severely damaged locality at Whakamaru near Mangakino recorded an overall decrease in stock carrying capacity of $19.8 \%$ ewe equivalents. In view of the propensity of grass grub to severely damage this class of country, the low economic surplus per acre, the high costs of alternative insecticides to DDT, and the rapid build up of grub populations, the future of much of the region for pastoral farming appears to be in jeopardy.

\section{INTRODUCTION}

GeNERALly the central plateau is regarded as marginal farmland. The impoverished nature of the soils and their loose, light and friable texture make them extremely prone to drought and grass grub attack.

Topographically, the area is regarded as moderate to steep hill country ranging in altitude from 300 to $670 \mathrm{~m}$ above sea level.

The better soils in the area are usually those on the hills while those on the valley floors are poorer and more drought prone.

Annual rainfall varies with altitude from between 1100 and $1400 \mathrm{~mm}$, with most precipitation in winter and early spring. Winters are cold and heavy frosts are common. Owing to the poor moisture retention qualities of the soil and the seasonal distribution of rain, soil moisture deficiencies are usually experienced from mid-summer to early winter. As a result, autumn growth is poor and peak pasture production occurs during the spring and early summer months.

Pasture production in the area is low. Over five years at the Wairakei Research Area, an average of 5,600 and $9,000 \mathrm{~kg} / \mathrm{ha} / \mathrm{yr}$ has been recorded from the flat and hill country, respectively. 


\section{DEVELOPMENT IN THE CENTRAL PLATEAU}

In the early 1930s the development of pastoral farming within the region was hampered by bush sickness. However, with the discovery of cobalt deficiency as the cause of this condition and the advent of aerial topdressing, huge tracts of land were successfully developed.

Serious grass grub damage soon erupted in the late 1940s and the rate of development slowed until in 1951 DDT became available for grass grub control. With the advent of DDT, and the resultant, cheap and efficient grass grub control, the increased production and the development of large areas of hitherto marginal land became possible.

Sheep and cattle numbers increased in the area to the stage when in the 1968-9 season the beef and sheep production from the Taupo and Rotorua counties have been estimated to give a return of 5.5 and 14.25 million dollars, respectively, a total for the whole region of 19.75 million dollars.

\section{AVERAGE FARM UNIT}

While it is appreciated that it is always dangerous to try to typify an area by citing an average farm as being representative of such a diverse area, it is felt that, in order to comprehend the current grass grub situation in the central plateau, some knowledge of the economics of farming within the region is essential. An average private farm in the region is 180 ha and carries 12 e.e.*/ha.

Avenues or patterns of production open to the farmer of the central plateau region range from pure sheep to different combinations of sheep and cattle. A limited amount of dairying is confined to the areas near Rotorua but more generally production is confined to cattle and sheep.

In order to examine relative profitabilities and gain some idea of the gross returns/ha in 1971, gross margins were calculated by subtracting direct expenditure from gross returns allowing for an interest rate of $8 \%$ for capital invested in stock (Table 1).

TABLE 1: GROSS MARGINS/HA FOR DIFFERENT PATTERNS OF PRODUCTION IN THE TAUPO HILL COUNTRY*

Gross Margin/ha

\begin{tabular}{|c|c|c|c|c|}
\hline Sheep: & & & & \\
\hline 1875 ewes and supporting stock .... & $\ldots$ & $\ldots$ & $\cdots$ & $\$ 49.52$ \\
\hline $\begin{array}{l}\text { Sheep/Beef: } \\
50 \text { Beef cows }\end{array}$ & & & & \\
\hline $\begin{array}{l}1576 \text { ewes and supporting stock .... } \\
100 \text { Beef cows }\end{array}$ & $\ldots$ & $\ldots$ & $\cdots$ & $\$ 52.33$ \\
\hline 1277 ewes and supporting stock .... & $\ldots$ & $\ldots$ & $\ldots$ & $\$ 55.14$ \\
\hline
\end{tabular}

*Typical farm 180 hectares carrying 12 e.e./ha.

The gross margin for a ewe was calculated on a $95 \%$ lamb survival with all lambs fattened, which gave a gross margin per ewe of $\$ 4.81$ and per hectare of $\$ 49.52$.

*Ewe equivalent (Coop 1965). 
A gross margin for a beef cow was calculated on an $85 \%$ calf survival, steer calves sold as weaners and culled heifers sold at 18 months, which gave a gross margin of $\$ 39.00 /$ breeding cow. In calculating gross margins/ha allowances have been made for carrying non-productive replacements and rams and/or bulls.

Gross margins/ha for sheep-cattle combinations show a rise for pure sheep from $\$ 49.52$ to $\$ 55.99 /$ ha for the highest beef to sheep ratio considered.

Clearly these figures only reflect the relative profitabilites for different patterns of production with similar fixed costs. Nevertheless, they amount to under half of those calculated for an established and productive farming area such as the Takapau district of Central Hawke's Bay and depict the marginal nature of farming in the region.

A cost of $\$ 15 / \mathrm{ha} / \mathrm{yr}$ covers the average fertilizer requirements of the area to maintain production at 12 e.e./ha. The soils of the central plateau are phosphate and sulphur demanding and, following development, have a high potash requirement. As much of the land has been recently settled, a major portion of gross returns may go to servicing mortgages. It is not unreasonable to place the net returns/ha from some of this land (depending on financial circumstances) at $\$ 20 / \mathrm{ha} / \mathrm{yr}$.

\section{COSTS OF GRASS GRUB CONTROL}

Although such cultural practices as spring cultivation, mob-stocking over the winter months, and the use of lucerne offer scope for grass grub control in some areas (Kain and Atkinson, 1970), for a great deal of the pumice hill country total reliance for grass grub control must at present rest with insecticides. The use of lucerne on the flats has proved successful, but a large proportion of the area is not traversible by tractor and the technology for oversowing lucerne into the pumice hill country is as yet not far enough advanced to make it a practical proposition.

The use of insecticides for grass grub control in this area revolves around aerially applied lindane, since the transient life of the organophosphate alternatives, "Mocap" and diazinon makes distribution too critical in comparison with an insecticide with a longer residual life for efficient control. Further, the dependence of organophosphate insecticides on soil moisture at, and rain immediately after application generally limits their use to ground applicators on dairy farms.

It is known that, in this region, the active soil life of lindane does not exceed 18 months and that, following insecticidal control with transient chemicals, populations build up to pest proportions within two seasons (Kain and Atkinson, 1968). Therefore, the probable frequency of application with lindane for efficient grass grub control would be every three years at a cost of $\$ 17 /$ ha or $\$ 5.76 / \mathrm{ha} / \mathrm{yr}$.

This cost in some instances may represent as much as a third to a quarter of the net return/ha/yr.

It is therefore not surprising that relatively little insecticide has been used. In many instances the uncontrolled outbreaks that have occurred have resulted from an understandable "wait and see", attitude of the farmers.

\section{CURRENT POSITION}

During the DDT era, grass grub damage within this region was usually confined to pastures that had remained untreated for a period in excess 
of three years, or that had recently been cultivated and sown to grass and where the delayed action of surface broadcast. DDT had allowed severe grub damage to occur. Few areas treated regularly with DDT suffered to any extent. Control was possible for as little as $\$ 3.71 /$ ha every three years.

A postal survey in 1971 within the Taupo Department of Agriculture Advisory District revealed that over 63\% of the farmers who replied were aware of the presence of grass grub damage on their properties; $43 \%$ stated they had a moderate to severe grass grub prublem.

This response has fortified observations within the region that outbreaks over the last four years have become more widespread and common. It is feared that this situation may lead to a very widespread post-DDT grass grub population explosion.

The resettlement of 60 dairy farmers in the Whakamaru district last year where dairy farming has been phased out, was in part caused by the inability of the farmers to economically control grass grub. This situation developed before that in the surrounding sheep farms as a result of the earlier restriction placed on DDT usage on dairy farms.

In order to gain some idea of the severity of grass grub depredations in the central plateau hill country, effects on stock numbers have been studied in a survey on five hill country sheep farms near Mangakino totalling 783 ha. Grass grub became obvious in the area in 1968 and had reached high levels by 1971 , when over $25 \%$ of the area was severely damaged. The decrease in stock numbers of this period are given in Table 2. Over the 1968-9 season, grass grub damage was aggravated by a summer drought over the summer and early autumn months. Between 1968 and 1970 , hogget numbers dropped by $29.9 \%$ and beef cattle by $37.8 \%$.

TABLE 2: STOCK NUMBERS WINTERED ON FIVE FARMS IN THE WHAKAMARU AREA WHICH WERE BADLY DAMAGED BY GRASS GRUB FROM 1969 TO 1971

\begin{tabular}{|c|c|c|c|c|c|c|c|c|}
\hline \multicolumn{9}{|c|}{ Number of Livestock Wintered* } \\
\hline Class & & & 1967 & 1968 & 1969 & 1970 & 1971 & $\%$ Change \\
\hline Ewes & $\ldots$ & $\ldots$ & 5764 & 5769 & 5995 & 6045 & 5955 & +3.3 \\
\hline Hoggets & & $\ldots$ & 1308 & 1172 & 1260 & 1025 & 918 & -29.9 \\
\hline Cows & $\ldots$ & $\ldots$ & 2070 & 2070 & 2142 & 1428 & 1530 & -26.1 \\
\hline $\mathrm{R}_{1} \dagger$ & $\ldots$ & $\ldots$ & 820 & 912 & 714 & 456 & 332 & -59.5 \\
\hline $\mathrm{R}_{2}$ & $\ldots$. & $\ldots$ & 660 & 945 & 265 & 250 & 325 & -50.8 \\
\hline Others & $\ldots$. & $\ldots$ & 50 & 45 & 55 & 40 & 50 & \\
\hline \multicolumn{9}{|c|}{ Number of E.E. } \\
\hline Sheep & $\ldots$. & $\ldots$ & 7072 & 6944 & 6740 & 6638 & 6450 & -8.8 \\
\hline Cattle & $\ldots$ & $\ldots$ & 3600 & 3977 & 2975 & 2005 & 2100 & -41.7 \\
\hline Total & $\ldots$ & $\ldots$. & 10672 & 10921 & 9715 & 8643 & 8550 & -19.8 \\
\hline
\end{tabular}

*Total for 5 farms.

$\dagger R_{1}$, yearling cattle. $R_{2}$, 18-months-old cattle.

The conversion of stock numbers to ewe equivalents to account for changes in classes of stock, in order to give an assessment of the fall in carrying capacity, gave an overall reduction of $19.8 \%, 8.8 \%$ reduction in sheep and $41.77 \%$ reduction in cattle. 
This sharp decrease in cattle numbers is caused by the inability of this class of hill country to support cattle once the turf has been undercut by grass grub, without precipitating erosion.

These figures demonstrate clearly the pest status of grass grub in this region.

The economic impact of reduced cattle numbers is shown by comparisons of the gross margin returned from pure sheep and from different proportions of cattle and sheep in Table 1.

The rehabilitation of damaged hill country requires, not only applications of insecticide, but also oversowing. Usually results from oversowing within the area are extremely variable and costs inclusive of insecticide amount to $\$ 32 /$ ha.

\section{CONCLUSIONS}

Nowhere is the pest status of grass grub higher than on the marginal farming land of the central plateau where annual costs of control represent a high proportion of the net annual return/ha.

We think it is fair to state that in such an economic and physical environment the grass grub creates an economic syndrome which is difficult to break without a more complete subsidy on insecticide. In the initial stages, farmers do not treat since they cannot afford the expense. Rather, they adopt the wait-and-see attitude which may give rise to more extensive damage in the following year, necessitating a reduction in stock numbers and therefore productivity.

Unless prices for meat and wool increase and so enhance the profitability of conventional farming within the region, the widespread use of insecticides at current prices is economically not feasible.

If lindane is not adequately subsidized, the agricultural production and potential of a large part of the central plateau will be crippled in the very near future.

Increased levels in productivity, arising from improvements in agronomic technology, will almost certainly increase the profitability of the Taupo hill country. Preliminary work on the introduction of lucerne in this environment has shown that this plant has up to twice the production of the conventional ryegrass pasture, plus the advantage that it is resistant to grass grub. The development of techniques for introducing lucerne and other high-producing species resistant to grass grub into this hill country could mitigate against the impact of the region's grass grub problem.

On the other hand, it is known that grub resistance to DDT, in some localities at least, is widespread, and the paths of cross resistance between the organochlorines are well known in other insects. Therefore, it would be unlikely if resistance to lindane did not quickly build up in those populations that hitherto were resistant to DDT. Further, overseas markets may impose still lower tolerance levels on lindane which may be impossible to meet. In either case, the possibility must be faced that lindane may not be active against, or permitted for, grass grub control in the near future. Failure to find a suitable replacement within this nerind would expose large areas of hill country dependent on aerial application of insecticide to grass grub attack.

The question which inevitably arises is that, as it was in the nation's interest to ban DDT, then is it not in the interests of the nation and the farmer to give more adequate assistance in the less reliable and/or more expensive replacement insecticides to preserve the productivity of pastoral farming? 


\section{ACKNOWLEDGEMENTS}

The authors acknowledge the help of D. S. Atkinson who was responsible for most of the analyses of the data presented.

\section{REFERENCES}

Coop, I. E., 1965. A review of the ewe equivalent system. N.Z. agric. Sci., 1 (3) : $13-8$

Kain, W. M.; Atkinson, D. S., 1968. Insecticide control of grass grub (Costelytra zealandica) in the mid North Island region of New Zealand. Proc. 21st N.Z. Weed \& Pest Control Conf.: 263-70.

; 1970. A rational approach to grass grub control. Proc. 23rd N.Z. Weed \& Pest Control Conf.: 180-3. 